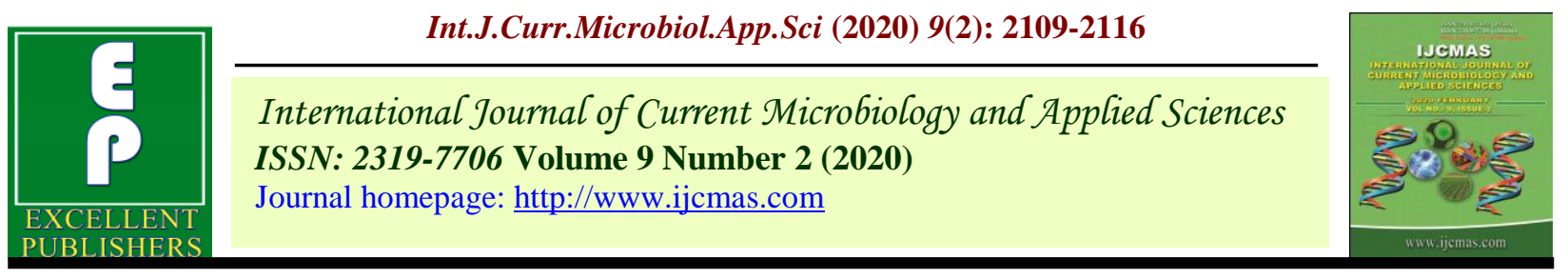

Original Research Article

https://doi.org/10.20546/ijcmas.2020.902.239

\title{
Study on Floral Traits of Male Sterile and Fertile Lines for Hybrid Development in Bread Wheat
}

\author{
Ashwin B. Dahake ${ }^{1}$, A. K. Chabra ${ }^{2}$, S. K. Sethi ${ }^{3}$ and Arun Kumar ${ }^{4 *}$ \\ ${ }^{1}$ Department of Genetics and Plant Breeding, CCS Haryana Agricultural University, \\ Hisar-125004 (Haryana), India \\ ${ }^{2}$ Department of Seed Science \& Technology, Bihar Agricultural University, \\ Sabour-813210 (Bihar), India \\ *Corresponding author
}

A B S T R A C T

Keywords

Floral traits,

heritability,

allogamy, glume,

anther, lodicules,

pollen viability

Article Info

Accepted:

15 January 2020

Available Online:

10 February 2020
Allogamyin the range of $0-5$ percent is reported in wheat which is beneficial for hybrid development. To know the floral traits as well as their heritability that influence allogamy, twenty eight genotypes of bread wheat comprising of both male fertile and male sterile lines were grown under timely sown conditions. Male sterile line D 2802-3A showed maximum glume opening angle $\left(30.33^{\circ}\right)$ and largest size of lodicules $(3.10 \mathrm{~mm})$. Minimum anther size was observed in WH $1472 \mathrm{~A}\left(0.94 \mathrm{~mm}^{2}\right)$ along with shortest filament length $(2.24 \mathrm{~mm})$ and lowest anther extrusion $(5.67 \%)$. Anther in male sterile was shriveled and thinner. Pollen viability was nearer to zero in all male sterile lines. Further, all the traits under study showed very high heritability in broad sense. The highest heritability was observed for filament length which is followed by pollen viability. Genetic advance was observed maximum for pollen viability followed by anther extrusion.

\section{Introduction}

Wheat constitutes the world's most important food crop and its different properties have made this crop the most important staple food of 35 percent population of the world. India in the recent past has emerged as second largest producer of the wheat after China. Wheat production has increased more than 17 times from 6.46 million tonnes in 1952 to 110.15 million tonnes in 2016-17 (Anonymous, 2018). The average yield has increased more than 4 times from 0.66 tonnes $\mathrm{ha}^{-1}$ in 1950 to 3.216 tonnes $\mathrm{ha}^{-1}$ in 2016-17.At present in India, wheat is the second most important cereal crop after rice grown under diverse agro-climatic condition. Despite this success, India cannot be complacent with regard to the efforts to produce more to meet the food security requirement. Due to ever-increasing 
population pressure, changing food habits and industrial needs, the demand for wheat is also increasing very rapidly. To meet the target of wheat production of 95 to 109 million tonnes by 2020 , we need to produce additional 1.5 million tonnes from the present level (Kumar, 1998). Since the scope of area expansion is very limited, vertical expansion needs to be explored to increase food production. In this endeavour, exploitation of heterosis in crop plants seems to provide the needful respite. Exploitation of heterosis was found equally remunerative and more productive in selfpollinated crops also. The reorientation in breeding strategy would play pivotal role in this endeavour.

The conventional wheat breeding methodology, in vogue, need integration of non-conventional approaches which may provide an alternative path for breaking the apparent wheat yield plateau. Among these, hybrid technology has paid rich dividends. Successful exploitation of heterosis/hybrid vigour on commercial basis in various crops is under progress but is still awaited in important crop like wheat.

Floral characters like glume opening angle, anther size, filament length, pollen viability, anther extrusion and size of lodicules are important for hybrid development. Wheat is an autogamous crop but 0-5 percent allogamy is reported which is desirable for hybrid development.

For large scale hybrid seed production the cross fertilising capacity of wheat must be increased. Hybrid wheat requires a transformation in flower behaviour from self to cross-fertilization (Guckert and Blouet, 1999). Wilson (1968a) suggested that the nature of flowering in wheat indicates that adaptation to cross-pollination was prevalent in its ancestors and may still be operating in present day cultivated forms.
So, there is need to develop breeding lines having floral traits which can support higher cross pollination. In this connection several research workers have done studies on the floral traits of wheat concerned with hybrid development. Allan (1980) and Sethi and Chhabra (1990) reported anther extrusion in the range of 80 and 97 per cent in wheat which is much higher. Ivofoid (1991) found that the increased hybrid seed production was associated with longer spikes and an increase in the number of spikelets spike ${ }^{-1}$.

Wilson and Ross (1962) observed that the tightness of the spikelet influences the width of separation of glume opening angle. Akhmedov (1983) found that sufficient degree of open flowering in male sterile lines allowed adequate hybrid seed set. Increasing of pollen production and dehiscence of pollen grains outside the floret is a necessary and important factor for increased seed-set. For fertilization pollen grains have to travel from source, male parents to female parents in seed production block without losing their viability.

Despite relative short viability in wheat pollen (Kison et al., 1986, Fritz and Lukaszewski, 1989), it was adequate for hybrid wheat production. Further, Singh and co-workers (2007) studied floral characteristics of spring wheat in Indo-Gangetic plains of north India and reported existence of significant quantitative variation among indigenous, exotic and adapted wheat germplasm.

Several research reports revealed that a systematic study on male sterility sources, their maintenance, fertility restoration, floral biology, extent of cross pollination and use of molecular markers would certainly pave the way to successful hybrid development programme in wheat crop. The present study was undertaken with the objective to search parental lines based on different floral traits of 
male sterile and fertile lines for hybrid development in bread wheat under timely sown conditions.

\section{Materials and Methods}

The experiment was carried out at the experimental farm and biotechnology laboratory of Department of Genetics and Plant Breeding, CCS Haryana Agricultural University, Hisar, Haryana. which is comes under North West Plain Zoneduring rabi season (November to April) of 2012-13 and 2013-14.Twenty eight genotypes in which twenty five male fertile lines (DBW 17, HD 2967, HD 3055, HD 3058, HD 3059, HUW 640, JAVW 584, Kanchan 97, P 11850, P 11852, PBW 343, PBW 550, PBW 621, PBW 648, PBW 651, RAJ 4228, RAJ 4229, RAJ 4230, WH 711, WH 712, WH 1081, WH 1061, WH 1062, WH 1063 and WH 1105) and three male sterile lines (D 2802-3A, WH 147A and WH 147 2A) were collected from wheat section and grown in a randomized block design with three replications.

Observations were recorded for characters related to floral traits that influence allogamy. The observations on floral traits that influence allogamy were recorded. Five randomly selected plants from each replication were selected and observations were recorded on three spikes (one main and two side tillers) plant $^{-1}$ for glumes opening angle (the angle between lemma and palea of the lateral florets in central spikelet of a spike was measured with the help of protector, degree), anther size (anther length and width determined under binocular microscope using ocular micrometer, $\mathrm{mm}^{2}$ ), anther colour (anther color was recorded as observed just prior to dehiscence and categorized into light yellow, dark yellow and greenish yellow), filament length (determined under binocular microscope using ocular micrometry, mm), pollen viability \{ pollen grains were examined after staining with acetocarmine and 2,3,5triphenyl tetrazolium chloride (TTC $0.5 \%$ ) at the time of anther dehiscence and $20 \mathrm{~min}$. thereafter and the viable (bright red) and dead pollens (white) were counted under microscope, number of viable pollen grains/ number of pollen grains in microscopic field $\mathrm{X} 100, \%$, anther extrusion (extruded anthers of two lateral florets of five central spikelets of a spike on both side, (10 spikelets/spike) from each of five spikes, spikelets of a spike/ $\Sigma$ ten central spikelets/spike $\mathrm{x} 2 \mathrm{X}$ $100 \%$ ), size of lodicules (determined under binocular microscope using ocular micrometry and was recorded as the average from two lodicules of one lateral floret from the central spikelet of the spike, mm). The data for different characters were statistically analysed on the basis of the model as described by Panse and Sukhatme (1967).

\section{Results and Discussion}

Replication-wise means of observations for floral traits of male sterile and fertile lines in all twenty eight genotypes were subjected to analysis of variance to know the significant differences among them and the mean sum of squares for various traits studied are presented in table 1. The Mean sum of squares values was highly significant for all the traits under observation.

Mean of observations were recorded on various floral traits related to allogamy in wheat genotype for twenty five pollen parents used for crossing with the three male sterile lines i.e., D 2802-3A, WH 147A and WH 147 2A. The mean values of twenty eight genotypes are mentioned in table 2.Glumes opening angle in the twenty eight parents were recorded and the values are ranged in between $4.67^{\circ}$ to $30.33^{\circ}$. The wider glumes opening were found in male sterile lines as compared to male fertile lines. Anther size measurement ranged from $0.94 \mathrm{~mm}^{2}$ to 5.08 
$\mathrm{mm}^{2}$ in the studied parents, revealed that this character showed wide variation. Anther size was small for male sterile line, being minimum in WH $1472 \mathrm{~A}\left(0.94 \mathrm{~mm}^{2}\right)$ and maximum in fertile lines i.e., WH 1105 (5.08 $\mathrm{mm}^{2}$ ). Range for filament length in all the parents were from 2.24 to $8.46 \mathrm{~mm}$. Filament length were shorter in male sterile line shown by WH $1472 \mathrm{~A}(2.24 \mathrm{~mm})$ and maximum filament length was in fertile line PBW 550 (8.46).

The pollen viability of parents when observed under light microscope revealed that most of the parents produced very high percentage of viable pollens, but some pollen parents produced lesser number of viable pollen with increased percentage of sterile/nonviable pollen. Range for pollen viability in pollen parents ranged from 0.02 (D 2802-3A) to 97 percent (PBW343). Pollen viability was recorded minimum i.e. nearer to zero in three male sterile lines viz., D 2802-3A (0.02\%), WH 147 A (0.06\%) and WH 147-2A (0.09 $\%)$. It indicated that these lines have almost stable sterility. The floral attribute of anther extrusion showed wide range of variability among the 28 parents under observation. Range for anther extrusion was 5.67 to 90.33 per cent. Anther extrusion was minimum in male sterile line and maximum in fertile lines.Size of lodicules ranged between 1.0 and $3.1 \mathrm{~mm}$. Size of lodicule was more in male sterile lines, maximum in line D2802-3A $(3.10 \mathrm{~mm})$, while smallest in male fertile lines PBW 651 (1.00 mm).

Genetic variability for traits viz., glumes opening angle, anther size, filament length, pollen viability, anther extrusion and size of lodicules among all parents were analyzed based on six parameters and presented in the table 3.0 .Phenotypic coefficient of variation (PCV) was higher than the genotypic coefficient of variation (GCV) for all the traits under study but the differences between PCV and GCV were very small. Genotypic coefficient of variation for glumes opening angle, anther size, filament length, pollen viability, anther extrusion, size of lodicules among the 28 parents were calculated as $47.57^{0}, 28.50 \mathrm{~mm}^{2}, 31.88 \mathrm{~mm}, 35.66 \%$, $35.99 \%$ and $51.25 \mathrm{~mm}$, respectively.

Phenotypic coefficient of variation (PCV) was calculated for glumes opening angle $\left(49.69^{\circ}\right)$, anther size $\left(28.95 \mathrm{~mm}^{2}\right)$, filament length $(32.05 \mathrm{~mm})$, pollen viability $(35.90 \%)$, anther extrusion $(37.53 \%)$ and size of lodicules $(32.58 \mathrm{~mm})$ among the parents, respectively. All the studied traits showed very high heritability in broad sense. The highest heritability was observed in the trait, filament length followed by pollen viability. The trait glumes opening angle showed lowest heritability among the entire trait.

The trait pollen viability was found maximum genetic advance followed by the trait anther extrusion and minimum genetic advance in the trait size of lodicules under study. In general, low genetic advance was observed in all the traits except two traits viz., pollen viability and anther extrusion. All the parents under study produced almost yellow anthers. Anther colour was observed in all parents just prior to dehiscence. The traits viz., glume opening angle, anther size, pollen viability, filament length, and anther extrusion in pollen parents were target traits for which genetic improvement is essential for success in hybrid wheat breeding.

Genetic variability parameters were calculated to derive information about the inheritance of traits and to obtain hint about scope of genetic improvement for these traits. Presence of genetic variability is the basic requirement to improve any trait in a population for attempting section based breeding programme. In the present investigation, the analysis of variance for 
agronomic, seed-setting of $\mathrm{F}_{1}$ hybrids and floral traits of male sterile and male fertile lines studied, revealed highly significant variation among the hybrids and genotypes. The similar results were observed by Singh (1992), Chowdhary et al., (1994), Gangashetti (2000), Tomarand Anblagan (2004) and Krishnendu (2012). Genetic variability was studied in terms of mean, range, genotypic coefficient of variation (GCV), phenotypic coefficient of variation (PCV), broad sense heritability, genetic advance under selection as percentage of population mean.

The range values reflect the extent of phenotypic variability for different characters, but it also includes genotypic, environmental and genotypic $\mathrm{x}$ environmental interaction component. Therefore, estimation of genotypic, phenotypic and environmental component of variance is necessary to obtained genotypic variation. To get an idea of relative extent of heritable and nonheritable variation, component variations for various traits were analysed. The higher value of PCV than GCV was observed, however differences between them was very small. It indicated that small amount of environmental effect is present. Phenotypic appearance of traits is due to its gene expression with small environmental effect.

High genotypic coefficient of variation and high heritability coupled with high genetic advance suggested involvement of additive type of gene effect in the inheritance of the characters under study. The present study revealed that significant gain could be expected from selection for the characters. High heritability was associated with moderate to low genetic advance in an indication of dominance and epistatic effect. Glume opening angle, anther size, filament length, pollen viability, anther extrusion and size of lodicules shows high heritability and has a scope of genetic improvement as indicated by their genetic advance value and genetic advance expressed as per cent of mean.

In present study, all the floral traits of male sterile and fertile lines studied used to make $\mathrm{F}_{1}$ hybrids viz., glume opening angle, anther size, filament length, pollen viability, anther extrusion and size of lodicules showed significant amount of variability. Among the parents studied, glumes opening angle was more in male sterile line, maximum inD 2802-3A $\left(30.33^{0}\right)$ line.

Minimum glume opening angle was in pollen parent PBW $651\left(4.67^{\circ}\right)$. Anther size was small for male sterile line; minimum for $\mathrm{WH}$ $1472 \mathrm{~A}\left(0.94 \mathrm{~mm}^{2}\right)$ and maximum in fertile lines WH $1105\left(5.08 \mathrm{~mm}^{2}\right)$. Male sterile anther was shriveled, thinner and smallest but fertile anthers were well-filled, larger and broader. All the male fertile lines without any exception showed longer filament as compared to male sterile lines. Filament length was observed shorter in male sterile line WH 147 2A (2.24 mm) and maximum in fertile line PBW 550 (8.46 mm). Pollen viability was nearer to zero in all male sterile lines however, maximum in male fertile lines.

Anther extrusion was in general low in male sterile line, WH 147 2A $(5.67 \%)$ and maximum in fertile line WH 712 (90.33\%). Size of lodicules was more in male sterility lines; largest in line D2802-3A (3.10) and smallest in male fertile lines PBW 651 (1.00). Similar observation were also reportedin wheat by Rajki (1962), Athwal and Kimber (1970), De Vrie (1974), Spirova (1980), Sethi and Chhabra (1990), Chhabra and Sethi (1991), Ueno and Itoh (1997), Singh (1992), Chowdhry et al., (1994), Brears and Bingham (1989), Gangashetti (2000), Tomar and Anblagan (2004), Krishnendu (2012). 
Table.1 Analysis of variance for the floral traits of male sterile and fertile lines

\begin{tabular}{|c|c|c|c|c|c|c|c|}
\hline \multirow{2}{*}{$\begin{array}{l}\text { Source of } \\
\text { variation }\end{array}$} & \multirow{2}{*}{$\begin{array}{l}\text { Degrees } \\
\text { of } \\
\text { freedom } \\
\text { (df) }\end{array}$} & \multicolumn{6}{|c|}{ Mean sum of squares } \\
\hline & & $\begin{array}{c}\text { Glumes } \\
\text { opening angle } \\
\text { (degree) }\end{array}$ & $\begin{array}{c}\text { Anther } \\
\text { size } \\
\left(\mathrm{mm}^{2}\right)\end{array}$ & $\begin{array}{c}\text { Filament } \\
\text { length } \\
(\mathbf{m m})\end{array}$ & $\begin{array}{c}\text { Pollen } \\
\text { viability } \\
(\%)\end{array}$ & $\begin{array}{c}\text { Anther } \\
\text { extrusion } \\
(\%)\end{array}$ & $\begin{array}{c}\text { Size of the } \\
\text { lodicules } \\
(\mathrm{mm})\end{array}$ \\
\hline Replications & 2 & 4.44 & 0.05 & 0.03 & 23.91 & 83.10 & 0.01 \\
\hline Genotypes & 27 & $132.69 * *$ & $3.34 * *$ & $8.13 * *$ & $2465.59 * *$ & $1470.72 * *$ & $0.80 * *$ \\
\hline Error & 54 & 3.91 & 0.04 & 0.03 & 10.75 & 43.05 & 0.02 \\
\hline
\end{tabular}
**Significant @ ( $=0.01)$

Table.2 Mean performance for floral traits of male sterile and fertile lines

\begin{tabular}{|c|c|c|c|c|c|c|c|}
\hline $\begin{array}{l}\text { Line } \\
\text { No. }\end{array}$ & Pollen parent & $\begin{array}{l}\text { Glumes opening } \\
\text { angle (degree) }\end{array}$ & $\begin{array}{c}\text { Anther } \\
\text { size } \\
\left(\mathrm{mm}^{2}\right)\end{array}$ & $\begin{array}{c}\text { Filament } \\
\text { length } \\
(\mathrm{mm})\end{array}$ & $\begin{array}{c}\text { Pollen } \\
\text { viability } \\
(\%)\end{array}$ & $\begin{array}{c}\text { Anther } \\
\text { extrusion } \\
(\%)\end{array}$ & $\begin{array}{l}\text { Size of the } \\
\text { lodicules } \\
(\mathbf{m m})\end{array}$ \\
\hline 1 & DBW 17 & 5.33 & 3.53 & 5.11 & 94.00 & 56.00 & 1.08 \\
\hline 2 & HD 2967 & 10.33 & 3.72 & 5.47 & 93.67 & 59.33 & 1.31 \\
\hline 3 & HD 3055 & 10.00 & 4.04 & 5.47 & 93.33 & 59.00 & 1.28 \\
\hline 4 & HD 3058 & 13.00 & 3.74 & 5.63 & 92.00 & 68.67 & 1.38 \\
\hline 5 & HD 3059 & 11.67 & 3.77 & 4.88 & 92.00 & 59.33 & 1.40 \\
\hline 6 & HUW 640 & 16.67 & 4.40 & 5.67 & 85.00 & 84.33 & 2.00 \\
\hline 7 & JAVW 584 & 14.33 & 4.82 & 4.77 & 94.00 & 63.33 & 1.66 \\
\hline 8 & Kanchan 97 & 14.00 & 3.25 & 4.40 & 83.67 & 66.33 & 1.74 \\
\hline 9 & P 11850 & 13.00 & 4.02 & 7.75 & 86.00 & 63.00 & 1.49 \\
\hline 10 & P 11852 & 6.00 & 3.38 & 2.92 & 94.33 & 46.00 & 1.06 \\
\hline 11 & PBW 343 & 11.67 & 3.47 & 4.60 & 97.00 & 65.00 & 1.18 \\
\hline 12 & PBW 550 & 15.33 & 4.93 & 8.46 & 88.00 & 64.33 & 1.60 \\
\hline 13 & PBW 621 & 13.67 & 3.82 & 5.21 & 94.67 & 63.67 & 1.47 \\
\hline 14 & PBW 648 & 18.00 & 4.04 & 7.21 & 90.33 & 83.67 & 1.43 \\
\hline 15 & PBW 651 & 4.67 & 3.63 & 5.61 & 86.33 & 50.33 & 1.00 \\
\hline 16 & RAJ 4228 & 16.00 & 3.86 & 5.12 & 82.00 & 86.67 & 1.88 \\
\hline 17 & RAJ 4229 & 8.33 & 3.60 & 4.54 & 79.00 & 53.00 & 1.49 \\
\hline 18 & RAJ 4230 & 9.33 & 2.80 & 3.17 & 80.67 & 60.00 & 1.50 \\
\hline 19 & WH 711 & 5.00 & 3.30 & 3.86 & 91.33 & 54.00 & 1.22 \\
\hline 20 & WH 712 & 19.67 & 4.02 & 4.64 & 94.67 & 90.33 & 2.29 \\
\hline 21 & WH 1081 & 14.00 & 4.73 & 7.84 & 89.33 & 83.33 & 1.51 \\
\hline 22 & WH 1061 & 12.67 & 4.33 & 5.41 & 94.67 & 77.00 & 1.50 \\
\hline 23 & WH 1062 & 13.33 & 4.39 & 5.94 & 87.00 & 82.00 & 1.69 \\
\hline 24 & WH 1063 & 18.33 & 4.93 & 5.55 & 88.00 & 88.33 & 1.99 \\
\hline 25 & WH 1105 & 5.67 & 5.08 & 7.88 & 94.67 & 52.67 & 1.04 \\
\hline 26 & D $2802-3 A$ & 30.33 & 1.42 & 2.713 & 0.02 & 11.00 & 3.10 \\
\hline 27 & WH 147 A & 28.00 & 1.10 & 2.307 & 0.06 & 11.33 & 2.73 \\
\hline 28 & WH 147 2A & 27.33 & 0.94 & 2.237 & 0.09 & 5.67 & 2.53 \\
\hline \multicolumn{2}{|c|}{ Grand mean } & 13.77 & 3.68 & 5.16 & 80.21 & 60.94 & 1.62 \\
\hline \multicolumn{2}{|c|}{ CV } & 10.35 & 5.12 & 3.23 & 5.21 & 6.09 & 4.23 \\
\hline \multicolumn{2}{|c|}{ CD @ (p=0.05) } & 3.23 & 0.31 & 0.27 & 5.36 & 10.57 & 0.25 \\
\hline
\end{tabular}


Table.3 Estimation of variability parameters in floral traits of male sterile and fertile lines

\begin{tabular}{|c|c|c|c|c|c|c|}
\hline Character & Mean & Range & PCV & GCV & $\mathbf{H}^{\mathbf{2}}$ & GA (\%) \\
\hline Glumes opening angle (Degree) & 13.77 & $4.67-30.33$ & 49.69 & 47.57 & 91.70 & 12.92 \\
\hline Anther size (mm $\mathbf{( m )}^{\mathbf{2}}$ & 3.68 & $0.94-5.08$ & 28.95 & 28.50 & 96.90 & 2.19 \\
\hline Filament length (mm) & 5.16 & $2.24-8.46$ & 32.05 & 31.88 & 99.00 & 3.37 \\
\hline Pollen viability (\%) & 80.21 & $0.02-97.00$ & 35.90 & 35.66 & 98.70 & 58.54 \\
\hline Anther extrusion (\%) & 60.94 & $5.67-90.33$ & 37.53 & 35.99 & 92.00 & 43.35 \\
\hline Size of the lodicules (mm) & 1.62 & $1.00-3.10$ & 32.58 & 31.25 & 92.00 & 1.01 \\
\hline
\end{tabular}

Wheat is self-pollinated crop due to cleistogamy and chasmogamy present in its flower structures. Wide glume opening angle and big lodicule size is desirable character for a female or male sterile line to promote outcrossing. The anther size, filament length, pollen viability and anther extrusion are desirable for male fertile or pollen parents.

Same pattern was observed in the present study. It indicated that presence of chasmogamy in wheat flower structure and chances to explore it in hybrid wheat breeding programme.

\section{Acknowledgement}

Author is very much thankful to scientific team CCS HAU, Hisar for having provided the technical support and laboratory facilities for the present investigation.

\section{References}

Akhmedov, M.A. (1983). Some features of flowering in bread wheat in relation to the problem of hybrid seed production. NuchnoteckhnichestkiiByulleten, 129, 5860.

Allan, R.E. (1980). Wheat in hybridization of crop plants, Fehr, W.R. and Hadley, H.H (Eds.) Madison, Wisconsin. pp. 709-720.

Anonumous, (2018). Annual Report-2017-18. Department of Agriculture, Cooperation \& Farmers Welfare, Ministry of Agriculture
\& Farmers Welfare, Government of India Krishi Bhawan, New Delhi.

Athwal, D.S. and Kimber, G. (1970). Anther size and pollen longevity in wheat/rye addition lines. Wheat Information Service, Kyoto Univ., 30:30-32.

Brears, T. and J. Bingham. (1989). Exploitation of heterosis in hybrid wheat using gametocides. Vortrage-furPlanzenznchtung 16, 397-407. In Science for Plant Breeding 27 Feb - 4 March 1989. Proc XII Cong. EUCARPIA (Gotting: German Federal Republic).BreedingImpact of DNA Revolution, Oct. 30-31, 2003, UAS, Dharwad, Abst. pp. 65-66.

Chaudhary, M.A., Mahmood, N and Khaliq, I. (1994). Pollen production studies in common bread wheat. Rachis11:68-72.

Chhabra, A.K., Sethi S.K. (1991). Inheritance of cleistogamic flowering in durum wheat (Triticum durum). Euphytica55:147-150.

Chowdhury, M.A., Mahmood, N. and Khaliq, I. (1994). Pollen production studies in common bread wheat. Rachis, 11: 68-72.

DeVrise, A. Ph (1971). Flowering biology of wheat, particularly in view of hybrid seed production- a review. Euphytica20:162170.

Fritz, S. E. and Lukaszewski, A. J. (1989). Pollen longetivity in wheat, rye and triticale. Plant Brreding, 102: 31-34.

Gangashetti, M.G. (2000). Studies on floral traits and cytoplasmic genic male sterile lines in relation to hybrid wheat, Ph.D. Thesis, CCS Haryana Agricultural University, Hissar, India. 
Guckert, A., Blouet, A., and K. Streiff, (1999). Possibilities for hybrid seed production in wheat. In: A.S. Basra (Ed.) The Haworth Press Inc., U.S.A., Heterosis and Hybrid Seed Production in Agronomic Crops, 81117.

Ivofoid, W. M., (1991). Biochemical and molecular characterization of wheat genotypes determined by RAPD Analysis. Acta AgriculturaeScandinavica, Section BPlant Soil Sience, 57(4):335-341.

Kison, H. U., Skiebe, K.,Fechner, M. And Nothnagel, T. (1986). Result of pollen studied using the fluorescein diacetate test of different crp plants and the consequences for breeding work. Archiv fur Zuchtungsforschung, 16: 293-302.

Krishnendu, G. (2012). Identification of fertility restorer and sterility maintainer for cytoplasmic genetic male sterile (CGMS) lines in wheat (Triticum aestivumL.) M.Sc.Thesis, CCS Haryana Agricultural University, Hissar, India.

Krishnendu, G. (2012). Identification of fertility restorer and sterility maintainer for cytoplasmic genetic male sterile (CGMS) lines in wheat (Triticum aestivumL.) M.Sc.Thesis, CCS Haryana Agricultural University, Hissar, India.

Kumar, P. (1998). Food demand and supply projections for India. Agricultural Economics Policy, 98-01. IARI, New Delhi, 141.

Panse, V.G. and Sukhatme, P.V. (1967). Statistical Methods for Agricultural Workers. Indian Council of Agricultural Research, New Delhi.

Rajki. E. (1962). Some problems of biology of flowering in wheat. Proceding of symposium of genetics and wheat breeding.Martonvasar, 4-72.
Sethi, S.K., and Chhabra, A.K. (1990). Inheritence of Cleistogamic flowering in durum wheat. Euphytica, 59(2): 147-150.

Sethi, S.K., and Chhabra, A.K. (1990). Inheritence of Cleistogamic flowering in durum wheat. Euphytica, 59(2): 147-150.

Singh, P.P. and Rathore, R.K.S. (1992). Fertility restoration capacity of four restorers in hybrid with CMS lines having Triticum timopheevicytoplasm, Indian Journal of Genetics, 52(2): 149-152.

Singh, P.P. and Rathore, R.K.S. (1992). Fertility restoration capacity of four restorers in hybrid with CMS lines having Triticum timopheevicytoplasm, Indian Journal of Genetics, 52(2): 149-152.

Singh, S.K., Arun, B., and Joshi, A.K. (2007). Comparative evaluation of exotic and adapted germplasm of spring wheat for floral characteristics in the Indo-Gangetic Plains of northern India. Plant Breeding, 126: $559-564$

Spirova, A. (1980). Inheritance of open flowering in wheat. Academic Bulgare des Sciences, 33: 417-419.

Tomar, S.M.S. and Anbalagan, S. (2004). Characterization of cytoplasmic male sterile line in wheat (Triticum aestivumL.) Indian Journal of Genetics, 64(4): 291-294.

Ueno, K. and Itoh, H. (1997). Cleistogamy in wheat: genetic control and the effect of environmental conditions. Cereal Research Communications, 25: 185-189.

Wilson, J.A. (1968 a). Problems in hybrid wheat breeding. Euphytica, 17: 13-33.

Wilson, J.A. and Ross, W.M. (1962). Male sterility interaction of the Triticum aestivumnucleus and the Triticum timopheevi cytoplasm. Wheat Information service, 14: 29.

\section{How to cite this article:}

Ashwin B. Dahake, A. K. Chabra, S. K. Sethi and Arun Kumar. 2020. Study on Floral Traits of Male Sterile and Fertile Lines for Hybrid Development in Bread Wheat. Int.J.Curr.Microbiol.App.Sci. 9(02): 2109-2116. doi: https://doi.org/10.20546/ijcmas.2020.902.239 